\title{
De unga förbrytarna på de kriminalpolitiska ideologiernas gungbräde
}

\author{
Av professor, jur. dr. INKERI ANTTILA, Helsingfors
}

Avsikten är att i det följande försöka beskriva de ideologiska utvecklingslinjerna i systemet rörande unga förbrytare, sådana de kan skönjas i beslutsfattandet och den offentliga debatten under de senaste decennierna. Härvid vill jag även visa att nya kriminologiska forskningsresultat anknyter till förskjutningar i den kriminalpolitiska ideologin.

\section{Allmänt om unga förbrytares särställning}

Finland har, liksom de andra nordiska länderna, länge haft bestämmelser om straffmyndighetsåldern, alltså om den minimiålder som krävs för straffbarhet. De flesta länders lagstiftning upptar också en övre åldersgräns, som anger den ålder vid vilken särbehandlingen, dvs. tillämpningen av antingen kvantitativt eller kvalitativt lindrigare påföljder, upphör.

Speciallagarna om unga förbrytare är av betydligt senare datum. Stiftandet av sådana lagar innebär också att man går mycket längre i tillämpandet av ideologin om ungdomars straffrättsliga särställning. Dylika system uppkom i flera länder i slutet av förra århundradet. Vid samma tid som det amerikanska systemet med särskilda ungdomsdomstolar spreds till många länder, uppkom i Norge en konkurrerande modell — barnskyddssystemet. Trots att man i den offentliga debatten ofta ville se dessa två modeller som varandras motsatser, hade de i själva verket mycket gemensamt. Båda utgår från den principen, att de unga bildar en grupp för sig, på vilken man bör nyttja andra påföljder än på de vuxna. I systemet med ungdomsdomstolar bibehölls visserligen bestämda åldersklasser i det straffrätttsliga kontrollsystemet medan de i barnskyddssystemet överfördes under vårdmyndigheternas kontroll. Men även om påföljderna i enlighet härmed fick något olika namn, låg de till sitt sakliga innehåll relativt nära varandra, det må sedan ha varit fråga om anstaltspåföljder eller öppna påföljder: de ungas särställning betonades kraftigt både i den straffrättsliga och den socialrättsliga lagstiftningen.

Artikeln, som baserar sig på en gästföreläsning vid Uppsala Universitet, är översatt med medel som beviljats av Expertkommittén för översättning av finskpråkig facklitteratur till svenska. 


\section{Vårdoptimismens glanstid}

Då man i Finland cirka 40 år sedan började planera en särskild lagstiftning om unga förbrytare erbjöd lagstiftningen i de övriga skandinaviska länderna en naturlig förebild. Trycket $i$ riktning mot vård ökades av den nyss förnyade barnskyddslagen, som redan innehöll stadganden om unga förbrytare. Den första lagen om unga förbrytare stiftades år 1940. Den är fortfarande gällande, i ändrat skick.

De viktigaste principerna i denna lag var följande:

— Det straffrättsliga kontrollsystemet gällde lagöverträdare som fyllt 15 år; yngre personer överfördes helt under barnavårdsmyndigheternas kontroll.

- Man kunde tillämpa åtals- och domseftergift på lagöverträdare som fyllt 15 men ej 18 år. Därvid hade åklagaren eller domstolen att göra anmälan till barnavårdsmyndigheterna för eventuella kontrollåtgärder.

- Villkorligt dömda 15-20 åringar ställdes enligt huvudregeln under övervakning.

- Vissa personer, som dömts till ovillkorligt frihetsstraff för brott begånget $\mathrm{i}$ åldern 15-20 år, kunde förordnas till ungdomsfängelse i stället för vanligt fängelse; frågan avgjordes centralt av ett specialorgan, där förutom juridisk sakkunskap även fångvårdsexpertis och psykiatrisk sakkunskap var representerad; strafftiden för den som förordnats till ungdomsfängelse förlängdes härvid med en lagstadgad termin.

- Med undantag av lindriga fall skulle s.k. personundersökning verkställas på personer som begått brott som 15-20 åringar. Härvid var avsikten att utreda „orsakerna till brottsligheten“.

Det nya systemet upplevdes som en stor seger i den offentliga debatten på 1940-talet. Vid den tiden såg man det som ett viktigt mål i kriminalpolitiken att indela förbrytare i olika grupper, som det skulle vara möjligt att med framgång tillämpa olika slags påföljder på. Speciella förhoppningar fästes vid övervakningen av villkorligt dömda samt den andra nya påföljdsformen, ungdomsfängelse. Man ansåg att ungdomsfängelse i princip i hög grad skiljde sig från det vanliga fängelset genom att det var en inrättning för uppfostran och undervisning.

Den nya lagen ansågs ännu på 1950-talet vara framstegsvänlig och betydelsefull. Genom en ökning av resurserna räknade man med att kunna förbättra de klena resultat som erhållits genom övervakning av villkorligt dömda. Då de stora förhoppningar man hyst beträffande ungdomsfängelse rasade, skyllde man främst på den dåliga prognosen för de ungdomar som hamnat $\mathrm{i}$ anstalter. Ingen ifrågasatte veterligen behovet av att placera de unga i en särställning, vare sig i Finland eller i de övriga skan- 
dinaviska länderna. Opinionerna utvisade vid denna tid i allmänhet en markerad behandlingsoptimism, där man i synnerhet betonade socialmyndigheternas ansvar och det ändamålsenliga $\mathrm{i}$ att i ett tidigt skede ingripa i sakernas gång. En ofta upprepad fras var, att ett brott begånget av en ung person alltid var ett symptom på abnormitet som man borde börja bota så tidigt som möjligt.

Reformarbete saknades inte helt ens under 1940-1950-talen. Den första av statsrådet tillsatta kommittén för förnyande av lagstiftningen om unga förbrytare arbetade redan $i$ slutet av 1940-talet. Betänkandet var i enlighet med tidsandan vårdideologiskt och ledde inte till andra lagstiftningsåtgärder än vissa ändringar av strafftiden för dem som förordnats till ungdomsfängelse. Denna reform framhävde ytterligare behandlingsmålsättningarna: $\mathrm{Nu}$ lämnades bestämmandet av straffitiden att bero på ett beslut, fattat i verkställighetsskedet, under det att detta tidigare skett automatiskt med stöd av lag. I praktiken mildrades likväl systemet genom reformen.

\section{Kritiken på 1960- och 19\%0-talen.}

„Den kriminalpolitiska atmosfären“ i Finland förändrades först på 1960-talet. Detta hade delvis samband med den uppmärksamhet som de nya kriminologiska forskningsresultaten rört. Det är skäl att särskilt nämna två forskningsområden: undersökningarna av den dolda brottsligheten samt undersökningarna av fängelsernas (och med dem jämförbara anstalters) verkningar.

Man kan väl hänföra de samnordiska undersökningarna av den dolda brottsligheten till den basforskning som medelbart haft en stor betydelse för det kriminalpolitiska beslutsfattandet i Finland. Materialet för undersökningarna utgjorde de åldersklasser som i början på 1960-talet kallades till militäruppbåd. Resultaten föreföll utvisa att det var statistiskt normalt att man i en viss ålder gjorde sig skyldig till brott.

Undersökningarna av den dolda brottsligheten föreföll att ställa behovet av vård $\mathrm{i}$ en tvivelaktig dager. Man började misstänka att strävandena att $\mathrm{i}$ behandlingssyfte upptäcka brottsligheten så tidigt som möjligt byggde på oriktiga premisser. Man kunde nämligen konstatera att trots att ungdomsbrottsligheten i och för sig oftast endast var ett övergående fenomen, var det just de gärningsmän som blivit upptäckta och särskilt de som blivit dömda till straff- eller tvångsvårdsanstalter som senare upprepade sitt brott. Härifrån var steget kort till stämplingsteorin. Som kriminalpolitisk slutsats frågade man om inte samhället borde reagera så lindrigt som möjligt och inte så strängt 
som möjligt, eftersom just den institutionaliserade brottslingsstämpeln såg ut att särskilja dem, som återföll i brott.

Under samma årtionde som undersökningarna av den dolda brottsligheten tilldrog sig expertisens intresse, företogs i Norden och särskilt i Norge flera undersökningar av straffanstalternas verksamhet och verkningar. De intagnas erfarenheter och utomstående sociologers iakttagelser föreföll utvisa att möjligheterna till samhällsanpassning i genomsnitt avtog i stället för att öka. De gamla föreställningarna om brottslighetssmitta och fängelserna som „högskolor för brottslighet“ fick nytt innehåll och ny bekräftelse. Som medel med vilka fängelsekulturen kunde motarbetas anfördes å ena sidan ökat bruk av villkorliga straff, å andra sidan arreststraffet, som skulle vara kortvarigt och verkställas i enskild cell.

Vid ovannämnda undersökningar jämförde man också traditionella straffanstalter med vissa vårdinrättningar. Man lyckades påvisa att tvångsvård $i$ anstalt inte var bättre än ett motsvarande anstaltstraff. I själva verket kunde den vara sämre $i$ vissa avseenden, bl. a. på grund av att de garantier för rättssäkerhet, som sedan gammalt fanns i det straffrättsliga kontrollsystemet, ingalunda alltid anslöt sig till det förfarande där någon förordnades till anstalt. Därför krävde man som kriminalpolitisk konklusion att den ineffektiva och orättvisa tvångsbehandlingen skulle avskaffas och ersättas med ett klart och tydligt straffsystem.

1960-talet känneteckades i allmänhet av en livlig debatt om kriminalpolitikens mål och medel. Då fäste man även i många sammanhang uppmärksamhet vid de problem som hängde samman med anhopningen av påföljder. Genom exempel tagna ur det praktiska rättslivet visade man att gärningsmannen kunde drabbas av många olika negativa sanktioner för samma brott; somliga av dem kallades straff, andra vårdåtgärder eller administrativa påföljder; en klass för sig utgjorde ytterligare de övriga faktiska påföljderna. Då sanktionskumulationen ofta var slumpmässig och sällan planerad, krävdes en grundlig utredning av situationen och lagändringar.

Det officiella reformarbetet satte i gång vid mitten av 1960talet. De första reformkraven riktade sig - såsom i det här sammanhanget ofta är fallet - mot två „ytterlighetskategorier“ inom kontrollklientelet, dvs. å ena sidan dem som internerats enligt lagen om farliga återfallsförbrytare och å andra sidan de unga lagöverträdarna. Man började bereda lagändringar beträffande båda dessa grupper. För de ungas del skedde det här så, att justitieministeriet tillsatte en 5-mans kommission med uppdrag att utarbeta ett betänkande med allmänna principer för reformarbetet. Kommissionen fick en sammansättning som med tanke på den tidens förhållanden representerade ett verkligt ny- 
tänkande: blott 3 av dess medlemmar var jurister och av de övriga medlemmarna var en sociolog och en psykolog; kommissionens sekreterare var sociolog. Kommissionens betänkande utformade sig till ett opinionsmässigt viktigt debattinlägg, ocksả om de konkreta förslag som ingick $\mathrm{i}$ betänkandet blott på vissa punkter har realiserats. Kommissionen påpekade hur allmän den dolda brottsligheten var och nämnde farorna för att människor ,,spårade in“ på en brottslig bana, vårdideologins misstag, brottslighetssmittan i fängelserna och det orättvisa i anhopningen av påföljder. Den kanske mest kontroversiella detaljen i kommissionens betänkande var förslaget om veckoslutsarrest som ett alternativ till långvarigare frihetsstraff. Kommittén ville reservera ungdomsfängelset enbart för särfall i behov av vård.

Kommissionen föreslog emellertid inte inskränkningar i de ungas särställning. Det gjorde inte heller den kommitté som tillsattes för att delvis fortsätta arbetet och som avgav sitt betänkande några år senare. Det kanske mest betydande av de förslag som denna kommitté gjorde, var tanken på̀ en radikal förkortning av strafftiden för unga personer som hamnade i straffanstalt, genom et slags förvandlingsstraffsystem. Förslagen ledde inte till ny lagstiftning.

Ingången av 1970-talet medförde vissa nya drag i den kriminalpolitiska debatten i Finland. Man kunde skönja en ny riktning i undersökningar och officiella publikationer, där man riktade uppmärksamheten från gärningsmannen tillbaka till brottet. Man krävde att straffen skulle utsättas i enlighet med brottet och den brottsliga vilja som där tagit sig uttryck, inte i enlighet med den uppfattning man erhållit om gärningsmannens personlighet och absolut inte med stöd av năgot presumtivt ,vårdbehov". Man betonade betydelsen av likställighet och en enhetlig rättstillämpning. Allmänprevention ansågs nu vara det viktigaste målet för det kriminalpolitiska systemet; detta mål ville man uppnå med ett system där straffen var så lindriga som möjligt men risken att bli ertappad för ett brott väsentligt kunde ökas. Denna nya ideologi satte även spår i lagstiftningen. Som följd av en lagändring minskade antalet s. k. farliga återfallsförbrytare som samtidigt var internerade från $200-300$ personer till mindre än tio. År 1976 avskaffades de automatiskt strängare strafflatituderna för återfallsförbrytare. Istället infördes i strafflagen straffmätningsdirektiv för domstolarna. Härigenom ville man förenhetliga rättspraxis och lansera s. k. normalstraff.

En annan riktning under 1970-talet betonade nödvändigheten av att skilja mellan tvång och service. Man konstaterade att tvångsmomentet var en väsentlig och nödvändig beståndsdel i det straffrättsliga påföljdssystemet. Däremot ville man se service som en verksamhet som det var statens skyldighet att anordna 
men där nyttjandet borde ske på basen av frivillighet. Sålunda kunde t. ex. systemet med obligatorisk övervakning av villkorligt frigivna inte längre motiveras med att övervakarens verksamhet var till nytta för dem som övervakades, i vård- eller servicesyfte, utan den obligatoriska övervakningen måste ses som ett slags „efterstraff“. I Kriminalvårdskommitténs betändande föreslogs därför en radikal förkortning av prövotiden, avskaffande av övervakningen och en betydande ökning av service-verksamheten, framför allt arbetsförmedling och hjälp vid anskaffande av bostad. Hittills har av förslagen förverkligats en betydande förkortning av prövotiden. Denna åtgärd har automatiskt minskat betydelsen av det obligatoriska övervakningssystemet.

Bevarandet av en särskild lagstiftning för unga förbrytare harmonierade illa med denna nya ideologi. Tiden var dock inte mogen för en radikal reform. En arbetsgrupp utarbetade visserligen på uppdrag av justitieministeriet åren 1973-1975 flera partiella reformförslag. De ledde likväl inte till lagstiftning.

\section{Den aktuella situationen}

År 1977 inträdde reformarbetet i ett nytt skede. Reformplanerna ingår i två nyss publicerade förslag. Det ena är Straffrättskommitténs principbetänkande, avgivet i mars 1977. Det andra förslaget har utarbetats av en s. k. enmanskommission på uppdrag av justitieministeriet. En beredning på två nivåer beror på att straffrättskommitténs betänkande innebär planering på lång sikt medan det nu färdigställda delförslaget är avsett att förverkligas redan under de närmaste åren.

Det gemensamma för alla förslag de senaste åren har varit att de ungas särställning i betydande mån borde inskränkas. Denna ståndpunkt har starkt påverkats, förutom av ovannämnda nya ideologier, av att det allmänna straffsystemet mildrats under de senaste decennierna. T. ex. åtals- och påföljdseftergift, som till en början endast var möjliga ifråga om förbrytare under 18 år, kan nu tillämpas på alla lagöverträdare. För unga lagbrytare finns det alltså två parallella system i det här avseendet. Förutsättningarna för beviljande av villkorlig dom har också lindrats. Tukthusstraffet är avskaffat. De gamla humanitetssynpunkterna förutsätter alltså inte längre nödvändigtvis att man betonar de unga förbrytarnas särställning.

En annan omständighet som också spelar en viss roll är utvecklingen inom fångvården. Man har gått in för att försöka $a v-$ lägsna sådana drag som försvårar en frigiven fånges anpassning till friheten. För att motarbeta den ofördelaktiga fängelsekulturen som särskilt blomstrar i slutna anstalter, har man ökat de öppna anstalternas andel och förbättrat fångens kontakter med omvärld- 
en, t. ex. genom fångpermissioner. Man har ökat möjligheterna till studier och hobbyverksamhet för fångar i alla åldrar. Unga förbrytare är således inte längre i behov av en sådan särställning som föreföll nödvändig ännu för tjugo år sedan.

I det följande redogörs för huvudpunkterna i reformerna enligt enmannakommissionens förslag, emedan största delen av de reformförslag som nämns även ingâr i Straffrättskommitténs betänkande eller ännu tidigare förslag:

Delförslaget innehåller bl. a. följande förslag om upphävande av gällande stadganden:

— De särskilda bestämmelser om åtals- och domseftergift som gäller unga förbrytare kan avskaffas och man skulle alltså tillämpa samma stadganden på vuxna och unga personer.

- Förutsättningarna för beviljande av villkorligt straff blir likaså de samma för unga personer och vuxna. Man skulle inte heller längre förordna om övervakning av de unga, utan innehållet $\mathrm{i}$ det villkorliga straffet skulle för dem, liksom för de vuxna, endast utgöras av ett uppskov med verkställigheten av straffet för en bestämd prövotid och straffets bortfallande om inget nytt brott inträffat under denna tid.

- Påföljden „ungdomsfängelse“ skulle avskaffas. Ett nytt stadgande skulle likväl intas i lagen. Enligt detta kunde en person under 18 år ådömas ovillkorligt fängelsestraff endast om detta absolut krävs med hänsyn till den allmänna laglydnaden eller synnerligen vägande skäl annars föreligger.

- Personundersökningar av förbrytare över 18 år skulle slopas. I lagen om unga förbrytare betraktades personundersökningarna som uttryck för en modern kriminalpolitik, eftersom man med hjälp av dem kunde ådöma varje gärningsman ett individualiserat straff. Ännu på 1960-talet såg man, i brist på forskningsresultat och bunden av traditionella tankemönster, utvecklingen av detta system som en viktig uppgift. Numera jämställer man inte mera brottslighet med en sjukdom som går att bota och ser inte som domstolens uppgift att ställa någon diagnos. Man har också konstaterat att betydande nackdelar ansluter sig till personundersökningarna bl. annat därför att ett brott genom dem kommer till gärningsmannens närmaste omgivnings kännedom.

I reformförslaget har man ändå bibehållit personundersökningarna för de yngsta åldersgrupperna från 15 till 18 år, närmast kanske i syfte att uppnå en viss koordinering med bestämmelserna i barnskyddslagen. Däremot skulle personundersökningar av äldre lagbrytare verkställas enbart på särskilt förordnande av domstolen. 
Enligt reformförslaget skulle lagen bibehållas oförändrad i följande avseenden:

- Samma allmänna lindring av alla straff, som sedan gammalt ingått i lagen, skulle fortfarande beviljas dem som begått brott innan de fyllt 18 år. Strafflatitudens maximum skulle fortfarande vara $3 / 4$ av det normala maximum och minimum samma som det allmänna minimum i ifrågavarande straffart, d. v. s. 14 dagar fängelse och 1 dagsbot.

- Trots att ungdomsfängelse som särskild påföljdsart, förordnad av ett särskilt organ (s. k. fängelsedomstol), skulle utgå ur lagen, skulle det vara möjligt att reservera vissa anstalter företrädesvis för unga fångar. Alla placeringsfrågor skulle avgöras av fångvårdsmyndigheterna och villkorlig frigivning skulle regleras genom allmänna stadganden.

Den princip i reformförslaget, enligt vilken systemet rörande unga förbrytare i hög grad skulle närma sig det allmänna straffsystemet, tar sig på ett intressant sätt uttryck även däri, att man föreslår två nya straffarter som vardera skulle komma att gälla både unga och vuxna. Dessa är straffvarning och straffövervakning.

Straffvarning är tänkt som ett s. k. allmänt huvudstraff och skulle utgöra ett alternativ, speciellt till villkorligt straff men även till bötesstraff, om bötfällning inte var ändamålsenlig med beaktande av den tilltalades ekonomiska situation. Den skulle innebära en allvarlig varning, avkunnad av domstolen och närmast vara avsedd för förstagångsförbrytare. Anteckning härom skulle för en kort tid göras i straffregistret.

Straffövervakning kunde på förordnande av domstol ansluta sig till villkorligt straff. Därmed avses att den dömde förordnas att anmäla sig hos polisen högst 6 gånger $\mathrm{i}$ veckan under en period på 1-3 månader. Avsikten är uttryckligen att införa en ny påföljd, utan inslag av vård. Det skulle helt enkelt röra sig om ,stämpling av pass“. Försummade den dömde sin anmälning, kunde det villkorliga straff som ådömts honom förordnas att gå i verkställighet.

Ovannämnda korta förteckning torde ge en bild av reformens ideologiska bakgrund. Man har där strävat till att göra straffsystemet så klart som möjligt. Såsom tidigare konstaterats har man sökt binda straffets stränghet vid brottet och den brottsliga vilja som där visats, inte vid gärningsmannens personlighet eller ett förmodat vårdbehov.

Syftet med reformen skulle inte vara att hindra unga fångar från att erhålla psykiatrisk vård, psykologisk terapi och yrkesutbildning. Men i framtiden skulle det vara fråga om ett straff på viss tid, vars längd inte skulle bestämmas enligt förmodat 
vårdbehov. Likaledes skulle man tydligt särskilja påföljder i frihet från vård på frivillig bas, som skulle stå till buds för villkorligt dömda och villkorligt frigivna.

Efter reformen kunde socialvården koncentrera sig på stödoch biståndsåtgärder utan kontrollpolitisk barlast. Detta skulle framhäva socialvårdens självständiga ställning. Samtidigt borde socialvårdens resurser kraftigt ökas.

Förverkligas reformförslagen, innebär det att cirkeln slutes: De unga förbrytarna återvänder till det allmänna straffsystemet. Det räcker med en enda särregel, enligt vilken en förbrytare under 18 år i princip får ett lindrigare straff än andra och endast i specialfall får dömas till fängelse. I alla andra avseenden skulle samma system gälla alla straffmyndiga förbrytare. 